\title{
CONSANGUINITY AND RISK OF CONGENITAL DEFECTS- A SYSTEMATIC REVIEW
}

\author{
Charmode Sundip Hemant ${ }^{1}$, Kadlimatti Huchechesha ${ }^{2}$
}

${ }^{1}$ Assistant Professor, Department of Anatomy, Government Medical College, Miraj and ESIC Medical College, Gulbarga, Karnataka, India.

2Professor and HOD, Department of Anatomy, Government Medical College, Miraj and ESIC Medical College, Gulbarga, Karnataka, India.

\begin{tabular}{l}
\hline ABSTRACT \\
BACKGROUND \\
Consanguineous unions are associated with an increased susceptibility to various forms of autosomal recessive inherited disease. \\
The role of consanguinity in causation of congenital defects is not clear, as various genetic as well as environmental/ epigenetic \\
factors are involved in their aetiology. \\
In this study, we analysed the effect of consanguinity as a risk factor in occurrence of congenital defects.
\end{tabular}

\section{MATERIALS AND METHODS}

Systematically reviewed recent and past studies with different designs, methodologies conducted in different regions of world on the same subject and compared their conclusions. The reasons and incidence of consanguineous unions, types of consanguineous unions were assessed.

Settings and Design- ESIC Medical, Gulbarga, Department of Anatomy, Systematic Review Article.

\section{RESULTS}

Almost all studies support the view that congenital defects occur commonly in consanguineous couples than non-consanguineous couples, but the study designs varied significantly.

\section{CONCLUSION}

Congenital malformations occur more commonly in consanguineous couples than non-consanguineous couples with first cousins being the commonest type. The available articles have inadequately studied the actual (genetic) role of consanguinity in causation of congenital anomalies with multifactorial aetiology. There is a need of large population-based studies determining influence of consanguinity on occurrence of chromosomal abnormalities, thereby resulting in congenital anomalies.

\section{KEY WORDS}

Consanguinity, Congenital Defects, Congenital Malformations, Consanguineous Unions, Risk Factors, Genetics, Environment, Genetic Counselling.

HOW TO CITE THIS ARTICLE: Hemant CS, Huchechesha K. Consanguinity and risk of congenital defects- a systematic review. J. Evolution Med. Dent. Sci. 2018;7(31):3552-3559, DOI: 10.14260/jemds/2018/798

\section{BACKGROUND}

Consanguineous unions lead to the descent of autosomal recessive genes inherited from the common ancestors of either of the child-bearing couples, potentially leading to disease depending on the prevalence of consanguineous unions and the genetic contribution to disease. ${ }^{1}$ Many congenital defects have a genetic component in its causation, hence consanguinity may prove as a risk factor, particularly since prevalence of consanguinity has reached over $50 \%$ in some areas of the world and in some populations. ${ }^{2} \mathrm{~A}$ consanguineous marriage is defined as union contracted between persons/ couple biologically related as second cousins or closer. ${ }^{3}$ The purpose of this article is to determine the role of consanguinity as a risk factor for occurrence of congenital defects.

'Financial or Other Competing Interest': None.

Submission 09-04-2018, Peer Review 10-07-2018,

Acceptance 19-07-2018, Published 30-07-2018.

Corresponding Author:

Charmode Sundip Hemant,

Department of Anatomy,

Government Medical College, Miraj and

ESIC Medical College,

Gulbarga, Karnataka, India

E-mail: sundip.charmode@yahoo.com

DOI: $10.14260 /$ jemds $/ 2018 / 798$
Hence, it is the responsibility of health care providers to care for families involved in consanguineous unions and discuss and manage potential health concerns in an appropriate manner. ${ }^{4}$ Despite the complexity in the aetiology of various congenital malformations consanguinity can act as a risk factor for its occurrence, particularly if the disease has a recessive or multifactorial inheritance pattern. This possibility has been explored by a number of groups, who have attempted to quantify the potential degree of increased risk. However, these studies have varied in their scope, design and analysis, and as a result, different conclusions were drawn. For this review, we performed a detailed analysis of recent and old published articles addressing consanguinity and congenital defects.

\section{MATERIALS AND METHODS}

We searched for all articles from MEDLINE, PUBMED (January 1958 - December 2017) using the Medical Subject Headings (MeSH) terms "Congenital defects, congenital malformations" and "consanguinity" limited to the English language, which yielded more than 100 articles. We focused on articles that studied effect of consanguinity on congenital defects and its correlation with parental age, education, occupation, intra/extrauterine mortality, parity, religion and we could shortlist 94 such original articles which matched our study directly or indirectly. 


\begin{tabular}{|c|c|c|}
\hline $\begin{array}{c}\text { Sl. } \\
\text { No. }\end{array}$ & Subject of the Article & $\begin{array}{c}\text { No. of } \\
\text { Studies }\end{array}$ \\
\hline 1. & $\begin{array}{c}\text { Consanguinity and its effects on child } \\
\text { growth }\end{array}$ & 1 \\
\hline 2. & $\begin{array}{c}\text { Consanguinity and its effects on congenital } \\
\text { defects }\end{array}$ & 45 \\
\hline 3. & $\begin{array}{c}\text { Consanguinity and its effects on } \\
\text { anthropometric parameters of child }\end{array}$ & 15 \\
\hline 4. & $\begin{array}{c}\text { Correlation of parental age with } \\
\text { occurrence of consanguineous marriages }\end{array}$ & 14 \\
\hline 5. & $\begin{array}{c}\text { Correlation of parental education with } \\
\text { occurrence of consanguineous marriages }\end{array}$ & 12 \\
\hline 6. & $\begin{array}{c}\text { Correlation of parental occupation with } \\
\text { occurrence of consanguineous marriages }\end{array}$ & 6 \\
\hline 7. & $\begin{array}{c}\text { Correlation of parity/ fertility with } \\
\text { occurrence of consanguineous marriages }\end{array}$ & 15 \\
\hline 8. & $\begin{array}{c}\text { Effect of consanguinity on incidence of } \\
\text { intra/extrauterine loss (stillbirths, } \\
\text { neonatal deaths etc.). }\end{array}$ & 31 \\
\hline 9. & $\begin{array}{c}\text { Effect of Inbreeding on increase variance of } \\
\text { tooth diameter }\end{array}$ & 1 \\
\hline 10. & $\begin{array}{c}\text { Correlation of religion with occurrence } \\
\text { of consanguineous marriages }\end{array}$ & 4 \\
\hline Table 1. We classified these 94 articles accordingly in \\
Table 1
\end{tabular}

Following Inclusion Criteria were used to Further Shortlist these 94 Studies for this Review Article-

1. Cross-sectional and longitudinal studies preferably retrospective studies were considered.

2. Studies conducted in regions among participants affected by radiation exposure, nuclear or bomb explosions or any other source responsible for congenital malformations were excluded.

3. Research articles who had studied the same objectives which were studied by the author in his own original study 5 and this review article were only considered to keep the discussion precise.

Amongst shortlisted 94 articles, 16 articles were selected as they were conducted with adequate sample size which gave statistically significant findings. Research articles studying too many variables were rejected. These 16 original research articles matched author's own study 5 in design, analysis and objectives studied-

- Total number of articles found: 94

- Total number of articles shortlisted: 16

- Total number of articles rejected: 1

- Statistical tests/ methods used: Nil.

\begin{tabular}{|c|c|c|}
\hline Sl. No. & Author & Reason for Rejection \\
\hline 1. & William Schull ${ }^{6} 1958$ & Results in this study were influenced by atomic explosions in Hiroshima and Nagasaki regions \\
\hline \multicolumn{2}{|c|}{ Table 2. Study that fulfilled the selection criteria but was Rejected } \\
\hline \multicolumn{2}{|c|}{}
\end{tabular}

\section{RESULTS}

\begin{tabular}{|c|c|c|c|c|c|c|c|c|c|}
\hline $\begin{array}{l}\text { Sl. } \\
\text { No. }\end{array}$ & $\stackrel{n}{\stackrel{0}{0}}$ & 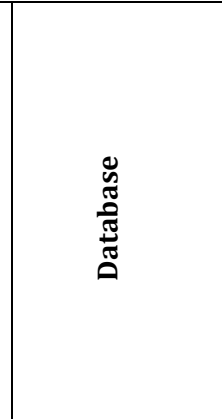 & 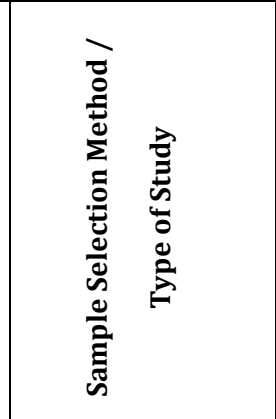 & 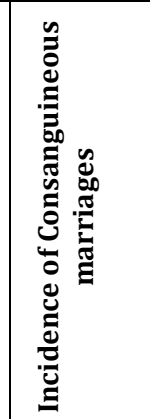 & 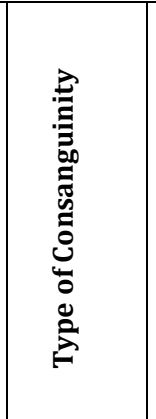 & 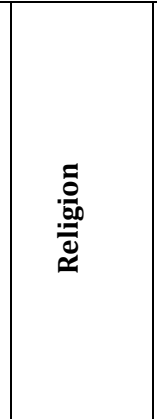 & 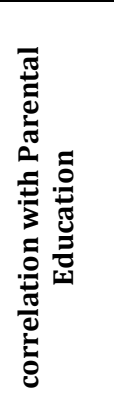 & 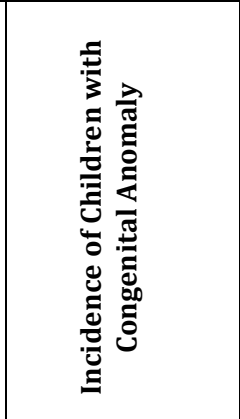 & 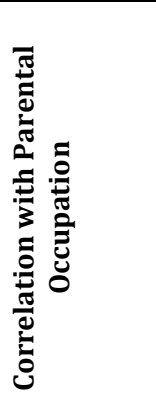 \\
\hline 1. & $\begin{array}{c}\text { Ranajit } \\
\text { Chakraborty, } \\
\text { Aravinda } \\
\text { Chakravarti }{ }^{7}\end{array}$ & $\begin{array}{c}\text { Book- Human } \\
\text { Genetics, } \\
\text { 05.01.1977, Vol } \\
\text { 36, Issue 1, 47- } \\
54\end{array}$ & $\begin{array}{c}\text { Cross-sectional } \\
\text { study- } 39,495 \\
\text { single birth records } \\
\text { were analysed, } \\
\text { India }\end{array}$ & Not & $\begin{array}{c}\text { Not } \\
\text { stated }\end{array}$ & Not stated & $\begin{array}{c}\text { Not } \\
\text { stated }\end{array}$ & \begin{tabular}{|c} 
Increased \\
incidence in \\
consanguineous \\
group than non- \\
consanguineous \\
$\quad$ group
\end{tabular} & Not stated \\
\hline 2. & Naderi S8 & $\begin{array}{c}\text { PubMed- } \\
\text { Medline- } 1979\end{array}$ & $\begin{array}{l}\text { Cross-sectional } \\
\text { study- } 9623 \text { new- } \\
\text { borns in Iran }\end{array}$ & $\begin{array}{c}\text { Not } \\
\text { stated }\end{array}$ & $\begin{array}{c}\text { Not } \\
\text { stated }\end{array}$ & Not stated & $\begin{array}{c}\text { Not } \\
\text { stated }\end{array}$ & \begin{tabular}{|c}
\multicolumn{1}{c}{ Increased } \\
incidence in \\
consanguineous \\
group than non- \\
consanguineous \\
$\quad$ group
\end{tabular} & Not stated \\
\hline 3. & $\begin{array}{l}\text { PSS Rao and } \\
\text { SG Inbaraj }{ }^{9}\end{array}$ & $\begin{array}{c}\text { Google scholar- } \\
1980\end{array}$ & $\begin{array}{c}\text { Prospective/ Cross- } \\
\text { sectional study in } \\
\text { India }\end{array}$ & Not stated & $\begin{array}{l}\text { No } \\
\text { significant } \\
\text { difference } \\
\text { s found in } \\
\text { both the } \\
\text { groups }\end{array}$ & Not stated & $\begin{array}{c}\text { Not } \\
\text { stated }\end{array}$ & $\begin{array}{c}\text { No significant } \\
\text { differences were } \\
\text { found in } \\
\text { incidence of } \\
\text { cong. defects } \\
\text { between both } \\
\text { the groups }\end{array}$ & Not stated \\
\hline
\end{tabular}




\begin{tabular}{|c|c|c|c|c|c|c|c|c|c|}
\hline 4. & $\begin{array}{l}\text { Asha Bai PV, } \\
\text { John TI et al } 10\end{array}$ & $\begin{array}{c}\text { PubMed- } \\
\text { Medline- } 1981\end{array}$ & $\begin{array}{c}\text { Case control study } \\
\text { in India }\end{array}$ & $41.4 \%$ & $\begin{array}{c}\text { Not } \\
\text { stated }\end{array}$ & $\begin{array}{c}\text { More } \\
\text { common } \\
\text { in Hindus }\end{array}$ & $\begin{array}{c}\text { Not } \\
\text { stated }\end{array}$ & \begin{tabular}{|l}
\multicolumn{1}{|c|}{ Increased } \\
incidence in \\
consanguineous \\
group than non- \\
consanguineous \\
$\quad$ group
\end{tabular} & Not stated \\
\hline 5. & \begin{tabular}{|} 
ML Kulkarni, \\
Mathew \\
Kurian $^{11}$
\end{tabular} & $\begin{array}{c}\text { PMC, US } \\
\text { National } \\
\text { Library of } \\
\text { Medicine- } 1990\end{array}$ & $\begin{array}{l}\text { Prospective cross- } \\
\text { sectional study } \\
\text { involving } 3700 \text { live } \\
\text { and stillbirths at } 3 \\
\text { hospitals in India }\end{array}$ & $26.5 \%$ & $\begin{array}{l}\text { Uncle- } \\
\text { niece } \\
\text { union } \\
\text { most } \\
\text { common } \\
\text { than first } \\
\text { cousins }\end{array}$ & $\begin{array}{c}\text { More } \\
\text { common } \\
\text { in Hindus }\end{array}$ & $\begin{array}{c}\text { Not } \\
\text { stated }\end{array}$ & $\begin{array}{c}\text { Significant } \\
\text { increase in } \\
\text { incidence in } \\
\text { consanguineous } \\
\text { group than non- } \\
\text { consanguineous } \\
\text { group }\end{array}$ & Not stated \\
\hline 6. & VK Jain et al12 & $\begin{array}{c}\text { PubMed- } \\
\text { Medline- } 1993\end{array}$ & $\begin{array}{c}\text { Case control study } \\
\text { done in JIPMER, } \\
\text { India }\end{array}$ & $\begin{array}{c}\text { Significan } \\
\text {-tly high } \\
\text { prevalenc } \\
\text { e }\end{array}$ & $\begin{array}{c}\text { First } \\
\text { cousins, } \\
50.6 \%\end{array}$ & Not stated & $\begin{array}{c}\text { Not } \\
\text { stated }\end{array}$ & \begin{tabular}{|c|} 
Significant \\
increase in \\
incidence in \\
consanguineous \\
group than non- \\
consanguineous \\
group \\
\end{tabular} & Not stated \\
\hline 7. & $\begin{array}{c}\text { Camilla } \\
\text { Stoltenberg } \\
\text { et al }{ }^{13}\end{array}$ & $\begin{array}{c}\text { PubMed- } \\
\text { Medline- } 1996\end{array}$ & $\begin{array}{c}\text { Retrospective } \\
\text { cross-sectional } \\
\text { study in 1,566,839 } \\
\text { birth records from } \\
\text { Medical Birth } \\
\text { Registry, Norway } \\
\text { from 1967-1993 }\end{array}$ & $\begin{array}{c}\text { Not stated } \\
\text { clearly }\end{array}$ & $\begin{array}{l}\text { No clear } \\
\text { result }\end{array}$ & $\begin{array}{c}\text { Pakistani } \\
\text { populatio } \\
\text { n had } \\
\text { higher } \\
\text { incidence }\end{array}$ & \begin{tabular}{|c|} 
Low \\
parental \\
education \\
is \\
associate \\
d with \\
increased \\
risk of \\
birth \\
defects
\end{tabular} & $\begin{array}{l}\text { Significant } \\
\text { increase in } \\
\text { incidence in } \\
\text { consanguineous } \\
\text { group than non- } \\
\text { consanguineous } \\
\quad \text { group }\end{array}$ & $\begin{array}{l}\text { Low parental } \\
\text { socio- } \\
\text { economic } \\
\text { status is } \\
\text { associated } \\
\text { with } \\
\text { increased } \\
\text { risk of birth } \\
\text { defects }\end{array}$ \\
\hline 8. & $\begin{array}{c}\text { Badaruddoza } \\
\text { Mohd. Afzal } \\
\text { et al }{ }^{14}\end{array}$ & PubMed- 1998 & $\begin{array}{l}\text { Prospective cross- } \\
\text { sectional study in } \\
1672 \text { singleton } \\
\text { consecutive births } \\
\text { in JNMC, Aligarh, } \\
\text { India }\end{array}$ & $37.98 \%$ & $\begin{array}{c}\text { First } \\
\text { cousins }\end{array}$ & Muslims & Negligible & \begin{tabular}{|c|} 
Significant \\
increase in \\
incidence in \\
consanguineous \\
group than non- \\
$\begin{array}{c}\text { consanguineous } \\
\text { group }\end{array}$ \\
\end{tabular} & Negligible \\
\hline 9. & $\begin{array}{c}\text { Rittler M, } \\
\text { Castilla EE15 }\end{array}$ & $\begin{array}{c}\text { PubMed- } \\
\text { Medline- } 2001\end{array}$ & $\begin{array}{l}\text { Case-control study } \\
\text { in Latin- US }\end{array}$ & $\begin{array}{c}\text { Not } \\
\text { stated }\end{array}$ & $\begin{array}{c}\text { Not } \\
\text { stated }\end{array}$ & Not stated & $\begin{array}{c}\text { Not } \\
\text { stated }\end{array}$ & $\begin{array}{c}\text { Significant } \\
\text { association of } \\
\text { consanguinity } \\
\text { and congenital } \\
\text { anomalies was } \\
\text { found }\end{array}$ & Not stated \\
\hline 10. & $\begin{array}{c}\text { A Nath, C Patil } \\
\text { et al } 16\end{array}$ & $\begin{array}{l}\text { Medind.nic.in/ } \\
\text { research } \\
\text { gate.net- } 2004\end{array}$ & $\begin{array}{l}\text { Prospective cross- } \\
\text { sectional study in } \\
\text { India }\end{array}$ & $36 \%$ & $\begin{array}{c}\text { First } \\
\text { cousins, } \\
54.4 \%\end{array}$ & $\begin{array}{c}\text { Muslims > } \\
\text { Hindus }\end{array}$ & $\begin{array}{c}\text { Not } \\
\text { studied }\end{array}$ & $\begin{array}{c}\text { Non-significant } \\
\text { increase in } \\
\text { incidence in } \\
\text { consanguineous } \\
\text { group than non- } \\
\begin{array}{c}\text { consanguineous } \\
\text { group }\end{array} \\
\end{array}$ & Not studied \\
\hline 11. & $\begin{array}{l}\text { Yunis K, } \\
\text { Mumtaz G } \\
\text { et al } 17\end{array}$ & $\begin{array}{c}\text { PubMed- } \\
\text { Medline- } 2006\end{array}$ & $\begin{array}{c}\text { Case control study, } \\
\text { Lebanon }\end{array}$ & $\begin{array}{c}\text { Not } \\
\text { stated }\end{array}$ & $\begin{array}{c}\text { First } \\
\text { cousins }\end{array}$ & Not stated & $\begin{array}{c}\text { Not } \\
\text { stated }\end{array}$ & \begin{tabular}{|l}
$\quad$ Significant \\
increase in \\
incidence in \\
consanguineous \\
group than non- \\
consanguineous \\
$\quad$ group
\end{tabular} & Not stated \\
\hline 12. & $\begin{array}{l}\text { Z Mosayebi } \\
\text { et al }{ }^{18}\end{array}$ & $\begin{array}{c}\text { PubMed- } \\
\text { Medline- } 2007\end{array}$ & $\begin{array}{c}\text { Prospective study, } \\
\text { Iran }\end{array}$ & $\begin{array}{c}\text { Not } \\
\text { stated }\end{array}$ & $\begin{array}{c}\text { Not } \\
\text { stated }\end{array}$ & Not stated & $\begin{array}{c}\text { Not } \\
\text { stated }\end{array}$ & \begin{tabular}{|c|} 
Significant \\
increase in \\
incidence of \\
cong. defects in \\
consanguineous \\
group than non- \\
consanguineous \\
group
\end{tabular} & Not stated \\
\hline
\end{tabular}




\begin{tabular}{|c|c|c|c|c|c|c|c|c|c|}
\hline 13. & $\begin{array}{c}\text { Sayee } \\
\text { Rajangam, } \\
\text { Rema Devi }{ }^{19}\end{array}$ & $\begin{array}{l}\text { Med India - } \\
\quad 2007\end{array}$ & $\begin{array}{c}\text { Retrospective } \\
\text { study done on } \\
1376 \text { individuals in } \\
\text { South India }\end{array}$ & $29.94 \%$ & $\begin{array}{c}\text { First } \\
\text { cousin }> \\
\text { uncle- } \\
\text { niece }\end{array}$ & $\begin{array}{c}\text { Not } \\
\text { studied }\end{array}$ & $\begin{array}{c}\text { Not } \\
\text { studied }\end{array}$ & \begin{tabular}{|} 
The study states \\
significant \\
association of \\
consanguinity \\
with MR and/or \\
MCA
\end{tabular} & Not studied \\
\hline 14. & $\begin{array}{l}\text { Khalid Yunis } \\
\text { MD, Reem El } \\
\text { Rafei et al20 }\end{array}$ & $\begin{array}{l}\text { Neo reviews- } \\
2008\end{array}$ & $\begin{array}{l}\text { Review study in } \\
\text { Lebanon }\end{array}$ & Not stated & $\begin{array}{c}\text { First } \\
\text { cousins }\end{array}$ & Not stated & $\begin{array}{c}\text { Not } \\
\text { stated }\end{array}$ & \begin{tabular}{|} 
In all studies \\
analysed in this \\
article, a \\
significantly \\
higher rate of \\
consanguinity \\
was found in \\
new-borns who \\
had congenital \\
anomalies \\
compared with \\
the 5 general \\
population
\end{tabular} & Not stated \\
\hline 15. & $\begin{array}{c}\text { Naeimeb } \\
\text { Tayebi et al21 }\end{array}$ & $\begin{array}{c}\text { PMC, US } \\
\text { National } \\
\text { Library of } \\
\text { Medicine- } 2010\end{array}$ & $\begin{array}{l}\text { Descriptive cross- } \\
\text { sectional study in } \\
\text { Iran }\end{array}$ & $25 \%$ & $\begin{array}{l}\text { First } \\
\text { cousins }\end{array}$ & $\begin{array}{c}\text { Not } \\
\text { studied }\end{array}$ & $\begin{array}{c}\text { Not } \\
\text { studied }\end{array}$ & $\begin{array}{c}\text { The prevalence } \\
\text { of anomalies was } \\
\text { higher in } \\
\text { consanguineous } \\
\text { marriages than } \\
\text { non- } \\
\text { consanguineous } \\
\text { marriages }\end{array}$ & Not studied \\
\hline 16. & $\begin{array}{c}\text { AL-Kandari } \\
\text { YY, Crews DE22 }\end{array}$ & $\begin{array}{c}\text { PubMed- } \\
\text { Medline- } 2011\end{array}$ & $\begin{array}{l}\text { Cross-sectional } \\
\text { study in Kuwait }\end{array}$ & Not stated & $\begin{array}{c}\text { First } \\
\text { cousins }\end{array}$ & Not stated & $\begin{array}{c}\text { Not } \\
\text { stated }\end{array}$ & \begin{tabular}{|c|}
\multicolumn{1}{|c|}{ Significant } \\
increase in \\
incidence of \\
congenital \\
defects in \\
consanguineous \\
group than non- \\
consanguineous \\
$\quad$ group
\end{tabular} & Not stated \\
\hline \multicolumn{10}{|c|}{ able 3. Research Articles included for this review that Fulfilled Selection Criteria } \\
\hline
\end{tabular}

Effect of Consanguinity on Congenital Defects Studied through Cross-Sectional/ Longitudinal Studies

Ranjit Chakraborty and A Chakravarti ${ }^{7}$ in their study analysed 39,495 single birth records from Mumbai under WHO survey and found that the incidence of major malformations is significantly higher among the inbred offspring (1.34\%) as compared to that among non-inbred ones $(0.81 \%)$. The inbreeding effect on perinatal mortality (stillbirths and mortality during the first few days of life) is also found to be significant.

Naderi $\mathrm{S}^{8}$ studied 9526 consecutive pregnancies as well as resulting in 9623 new-borns. There were 7261 new-borns from non-consanguineous parents and 2362 (24.5\%) babies from consanguineous marriages. The incidence of congenital abnormalities in new-borns of non-consanguineous parents was $1.66 \%$ as compared to $4.02 \%$ for new-borns of the consanguineous group. Major and multiple malformations were found to be slightly more common in the Consanguineous group. Prematurity, prenatal mortality rate and congenital abnormalities were more common in the consanguineous group.

Probably the closer the familial relationship of the parents, the greater the chances of congenital abnormalities.
PSS Rao, SG Inbaraj ${ }^{9}$ studied pregnancies of over 20,000 married women from rural and urban samples in North Arcot district were identified and investigated to study the effects of inbreeding like incidence of congenital anomalies, length of gestation and body measurements. No significant differences existed in the incidence of congenital anomalies among offsprings between the consanguineous and nonconsanguineous marriages in the rural or in the urban area. Neither were any significant trends seen by degree of consanguinity or by birth order or by the different age groups. The types of malformations and their frequency seen in the consanguineous and non-consanguineous groups were similar. It is suggested that long-term inbreeding does not lead to appreciable effects on foetal growth and development.

ML Kulkarni and Mattews Kurian ${ }^{11}$ studied a total of 3700 consecutive live and stillbirths taking place at three hospitals between November 1985 and March1987 and found that total of $26-5 \%$ of the total births in the present study were to consanguineous couples. The Hindus had a consanguinity rate of $28-1 \%$, while the Moslems had a consanguinity rate of $21.3 \%$. Uncle-niece marriage was the most common form of mating $14.5 \%$ followed by first cousin marriage $10.1 \%$. The frequency of malformations of major systems in consanguineous couples was significantly higher in our study. 
These findings were matched with WHO collaborative study 23 conducted at 24 centres in 1966.

Camilla Stoltenberg et al ${ }^{13} 1996$ in their study estimated the effects of consanguinity after adjusting for socioeconomic factors, maternal age, parity, year and place of birth. There was a two-fold increase in the proportion of children with birth defects among first-cousin parents in all groups considered. The risk of birth defects was higher in the Pakistani population as a whole compared with the other groups. This difference is explained by the high frequency of consanguineous marriages in the Pakistani population. Negative relation was found between parental educational levels and frequency of consanguinity. Similar findings have been demonstrated in previous studies.6,8,24,25

Badaruddoza Mohd. Afzal et al14 1998 studied a total of 1672 singleton consecutive births in JNMC, Aligarh and found the incidence of congenital malformations among the consanguineous being significantly higher than that among the non-consanguineous marriages. First cousins were the most common consanguineous union.

AK Nath et al $^{16}$ in a study conducted in Shindoli village amongst resident married women (500) found that the frequency of consanguinity was $36 \%$, which is less than that observed in other studies in South India. ${ }^{26-28}$ This could be attributed to the increasing modernisation, due to which the chances of such marriages are on the decline. Muslims showed a higher frequency of consanguinity as compared to Hindus. This finding is in contrast to that found in other studies, wherein consanguineous marriages were more among the Hindus. The most frequent type of consanguineous marriage was between first cousins (54.44\%). Foetal losses before 28 weeks were higher in consanguineous group as compared to non-consanguineous group. The study, however, did not show a significant difference in the number of congenital malformations between the consanguineous and non-consanguineous groups.

Z Mosayabi18 2007 in his study determined the types, patterns and prevalence of congenital malformation among the offspring of consanguineous and non-consanguineous parents. In this prospective study of 3529 neonates delivered alive during a 1-year period, 109 had congenital malformations (3.09/ 1000 live births). The rate of congenital malformation was $2.0 \%$ among neonates from nonconsanguineous marriages and $7.0 \%$ from consanguineous marriages. The most common malformations were genitourinary (32.1\%), musculoskeletal (22.0\%) and cardiovascular (14.7\%). Of the total malformed infants, $8.3 \%$ died within the neonatal period. Male infants were at greater risk for birth malformations. A history of congenital malformation was more common in siblings of consanguineous than non-consanguineous marriages.

Sayee Rajamgam, Rema Devi ${ }^{19}$ in their retrospective study done by collecting information from 1376 individuals with MR and/or MCA stated that consanguinity seemed to have a significant association with MR and/ or MCA. Consanguinity is considered to be an aetiological factor for increased occurrence of MCA and the subsequent morbidity/ mortality. These findings were supported by Bromikar et al ${ }^{29} 2004$ Naderi $S^{8}$ 1979, Anand et al ${ }^{30}$ 1998, Bittles ${ }^{31}$ 2001, Bittles ${ }^{32}$ 2002 and Stevenson ${ }^{23} 1966$.

Nayemi Tayebi et al21 in 2010 in a descriptive, crosssectional study with consecutive sampling of new-born babies, who had been delivered at Shahid-Sadoughi Hospital, Yazd, Iran during a 9 months period from April to December 2008 found that the frequency of malformations in this study was higher compared with other studies which have been conducted in Iran. This may be due to industrial pollution. In this study, the gender of the foetus did not affect the prevalence of $\mathrm{CM}$ and both genders were equally distributed. The prevalence of anomalies was higher in consanguineous marriages than non-consanguineous marriages.

AL-Khandari YY22 studied a total of 9104 married Kuwaiti females aged 15 - 79 years from different backgrounds selected at ten primary health care centres from six governorates in Kuwait and stated that significant differences were found in the occurrence of genetic diseases in consanguineous couples' offspring (4.88\%) compared with those of non-consanguineous couples (4.13\%). The results also show significant differences in frequencies of genetic/ environmental diseases in consanguineous couples' offspring $(8.59 \%)$ compared with those of non-consanguineous couples $(8.23 \%)$. A higher frequency of genetic diseases was found in first $6.97 \%$, second $6.78 \%$ and third-cousin $6.46 \%$ couples offspring compared with those of non-consanguineous couples. The frequency of congenital disabilities in the offspring of couples from consanguineous marriages $(2.9 \%)$ is higher than that in the offspring of non-consanguineous marriages $(2.3 \%)$. First-cousin marriages have the highest frequency $(3.5 \%)$ of congenital disabilities compared with other kinds of marriages $(2.1-2.3 \%)$.

\section{Consanguinity in Congenital Defects Studied through Case Control Studies}

Asha Bai PV et al ${ }^{10}$ studied 156 consanguineous marriages in comparison with 221 non-consanguineous marriages and found that developmental anomalies were significantly more frequent among the offspring of consanguineous parents. Among the 377 marriages, 156 (41.4\%) were consanguineous and 221 (58.6\%) were non-consanguineous. Consanguinity was more prevalent among Hindus than among Muslims or Christians. The frequency of developmental anomalies was significantly more frequent among the children of consanguineous parents.

VK Jain et $\mathrm{al}^{12}$ in his study undertaken in JIPMER, Pondicherry, South India, wherein four hundred children with existing congenital developmental disorders were studied with regard to their consanguineous parentage and compared with 1,000 randomly selected patients attending the paediatric outpatient department. There was a significantly higher prevalence of consanguinity in the study group. The common type of consanguineous marriages was first cousins $(50.6 \%)$. The frequency of consanguinity was significantly higher, especially with autosomal recessive disorders $(\mathrm{p}<$ 0.001), congenital heart diseases ( $p<0.001$ ), multiple malformations $(\mathrm{p}<0.001)$, neurological malformations $(\mathrm{p}<$ 0.005), chromosomal disorders $(p<0.01)$, genitourinary disorders $(\mathrm{p}<0.02)$ and mental retardation-developmental disorders $(\mathrm{p}<0.02)$.

Castilla EE and Rittler ${ }^{15}$ in 2001 in their study observed a significant association with parental consanguinity for three congenital anomaly types: hydrocephalus, postaxial hand polydactyly and bilateral cleft lip +/- cleft palate, while three additional anomalies namely cephalocele, microcephaly and hand + foot postaxial polydactyly showed a positive association. 
Yunis K and Mumtaz G17 in 2006 in their case-control trial studied 173 new-borns having one or more congenital heart disease admitted to the Neonatal Intensive Care Units of participating hospitals during 3-year period from January 1 , 2000 to December 31, 2002 and compared them with controls consisting of a random sample of 865 new-borns without a congenital heart disease admitted to the NICU during the same period and found that first cousin consanguinity is significantly associated with an increased risk of congenital heart disease. Infants born to first cousin marriages had a 1.8 times higher risk of having a congenital heart disease diagnosed at birth compared to those born to unrelated parents.

\section{Effect of Consanguinity on Congenital Defects Studied through Review Studies}

Khalid Yunis, Reem SL Rafel 20 in 2008 in their review article stated that all studies reviewed showed a significantly higher rate of consanguinity was found in new-borns who had congenital anomalies compared with the general population. Also stated that most common form of consanguineous union was between first cousins, i.e. third-degree relationship.

\section{DISCUSSION}

The majority of studies support a relationship between consanguineous parentage and congenital defects (Table 3). Many studies used cross-sectional as well as case control designs and included cases of congenital defects diagnosed by methods such as ultrasonography records, interviewing the mothers etc. The analyses of cases and controls hence are critical. A few important points should be considered. First to what extent could confounding play a role in differences between case and control groups? Could the choice of certain cases and controls inadvertently lead to elevated or deflated effect sizes that are attributed to consanguinity? Many of these studies use controls from the same hospital or from the same geographic region as the cases to minimise potential confounders. Second, how was consanguinity defined and determined?

Most studies determined consanguinity and classified it as first and second cousin unions, although some studies failed to indicate how consanguinity had been defined. The history of consanguinity and other information related to type of congenital defect, parental education, occupation, religion, birth order etc. relied largely on the report by the parent of a child with congenital defect collected through questionnaire. There are increased chances of reporting bias or recall bias, which can affect the conclusions.

In PSS Rao, SG Inbaraj ${ }^{9}$ study, lay women interviewers fluent in local language with some training were employed for collecting information and identifying congenital malformations in new-borns. Chances of errors in identifying and categorising congenital defects from such interviewers cannot be ruled out. In A Nath et al ${ }^{16}$ study, type of personnel employed for interviewing women for data collection were not mentioned. Such data received from women participant cannot be error free. How consanguinity was defined and determined also was not described in this study. Similarly, in studies by AL-Kandari YY, et al ${ }^{22}$ in 2011 and Asha Bai PV et al10 1981 data was collected using questionnaires from mothers. Sayee Rajangam, Rema Devi ${ }^{19}$ in their study collected data from available information on 1376 individuals with MR and/ or MCA. It was not clearly described how consanguinity was defined and determined and how congenital defects were classified.

Ranjit Chakraborty, A Chakravarti ${ }^{7} 1977$, Naderi $S^{8}$ in 1979, ML Kulkarni et al11 in 1990, VK Jain et al12 in 1993, Camilla Stoltenberg et al ${ }^{13}$ in 1996, Badaruddoza Mohd. Afzal et al14 1998, Yunis K, Mumtaz G et al ${ }^{17}$ 2006, Z Mosayebi et al18 in 2007, Naeimeb Tayebi et al21 in 2010, Rittler M and Castilla EE15 in 2001 in their studies collected data from hospital medical records, medical birth register which was recorded and maintained by medical personnel. Conclusions of such studies were more assuring.

Almost all the studies reviewed agreed and supported the point that congenital malformations were occurring more commonly in consanguineous couples than nonconsanguineous couples except PSS Rao, SG Inbaraj 1980. Many studies, 19,29,30,31,32 agreed that consanguinity has a significant association with congenital defects, but its effect on congenital anomalies was non-significant. Congenital anomalies have diverse causes, the level of involvement of genetic component in its causation varies and is reflected by observed association of consanguinity with some anomalies, e.g. positive association was found between first cousin marriage and septal defects, $17,33,34,35,36$ but the risk of transposition of great vessels and of coarctation of the aorta was not significantly increased with consanguinity. $17,33,35$ What about other minor congenital heart defects? Populationbased studies that capture large number of lesions and that quantify relatedness will be helpful. ${ }^{37}$ Counselling in families with consanguinity and congenital anomalies is often performed. In absence of recognisable pattern of disease inheritance, families are presented with an empiric risk for congenital anomalies based on population data that may or may not consider the type of lesion. This risk may be modified depending on the individual family history and other clinical risk indicators and may be further adjusted due to the presence of consanguinity, although the degree of risk used in counselling has been variable. ${ }^{38}$ Based on our review of these articles, we recognise that future large population-based studies of birth defects should incorporate measures of genetic relatedness into their assessment and analysis, and recurrence of disease should be tracked. We still need to strive to understand the relative contribution of genetics versus the environment in congenital defects. If we can determine the proportional effect of consanguinity on disease, this may help determine the genetic contribution to a specific complex condition or the comparative role of genetics versus environmental influences.

Formation of a better understanding of the relationship between consanguinity and congenital anomalies will help to implement more accurate genetic counselling and more effective clinical management. We provide following suggestions: (1) Patients involved in consanguineous unions, should be aware of potential health risks and should assess them based on background population risk, effect of consanguinity, relevant family history and clinical assessment. They should not refer only to the data presented in the literature, for calculating magnitude of health risks instead should take the individual medical history and other potential indicators of that disease in consideration. (2) Healthcare providers and patients should be continuously trained about the importance of the medical family history 
while dealing with congenital anomalies. (3) Focus on prevention of diseases rather than its management. (4) Genetic predispositions to any disease should be investigated thoroughly. (5) The issue of consanguinity and consanguineous unions should be treated as a global health issue.

\section{CONCLUSION}

- Congenital malformations occur more commonly in consanguineous couples than non-consanguineous couples.

- First cousins are the commonest type of consanguineous unions occurring all over the world.

- Consanguinity has a significant association with congenital defects, but its effect on congenital anomalies as genetic aetiology is non-significant.

- The available articles have inadequately studied the actual (genetic) role of consanguinity in causation of congenital anomalies with multifactorial aetiology.

- There is a need of large population based studies determining influence of consanguinity on occurrence of chromosomal abnormalities, thereby resulting in congenital anomalies.

\section{REFERENCES}

[1] Shieh JTC, Bittles AH, Hudgins L. Consanguinity and the risk of congenital heart disease. Am J Med Genet A 2012;158A(5):1236-41.

[2] Bittles AH. A community genetics perspective on consanguineous marriage. Community Genetics 2008;11(6):324-30.

[3] Bittles AH, Black ML. Consanguinity, human evolution and complex diseases. Proc Natl Acad Sci 2010;107(Suppl 1):1779-86. Consanguinity definition. en.wikipedia.org/ wiki/ Consanguinity.

[4] Bennett RL, Motulsky AG, Bittles A, et al. Genetic counseling and screening of consanguineous couples and their offspring: recommendations of the National Society of Genetic Counselors. J Genet Couns 2002;11(2):97-119.

[5] Charmode SH. Effect of consanguinity on congenital deffects. Journal of Evolution of Med and Dent Sci 2015;4(43):7461-71.

[6] Schull WJ. Empirical risks in consanguineous marriages: sex ratio, malformation and viability. Am J Hum Genet 1958;10(3):294-343.

[7] Chakraborty R, Chakravarti A. On consanguineous marriages and genetic load. Human Genetics 1977;36(1):47-54.

[8] Naderi S. Congenital abnormalities in newborns of consanguineous and non-consanguineous parents. Obstet Gynecol 1979;53(2):195-9.

[9] Rao PSS, Inbaraj SG. Inbreeding effects on fetal growth and development. Journal of Medical Genetics 1980;17(1):27-33.

[10] Bai APV, John TJ, Subramaniam VR. Reproductive wastage and developmental disorders in relation to consanguinity in south India. Trop Gregor Med 1981;33(3):275-80.

[11] Kulkarni ML, Kurian M. Consanguinity and its effect on fetal growth and development: a south Indian study. J Med Genet 1990;27(6):348-52.
[12] Jain VK, Nalini P, Chandra R, et al. Congenital malformations, reproductive wastage and consanguineous mating. Aust N Z J Obstet Gynaecol 1993;33(1):33-6.

[13] Stoltenberg C, Magnus P, Lie RT, et al. Birth defects and parental consanguinity in Norway. American Journal of Epidemiology 1997;145(5):439-48.

[14] Badaruddoza, Afzal M, Ali M. Inbreeding effects on the incidence of congenital disorders and fetal growth and development at birth in North India. Indian Pediatrics 1998;35(11):1110-3.

[15] Rittler M, Liascovich R, López-Camelo J, et al. Parental consanguinity in specific types of congenital anomalies. American Journal of Medical Genetics 2001;102(1):36-43.

[16] Nath A, Patil C, Naik VA. Prevalence of consanguineous marriages in a rural community and its effect on pregnancy outcome. Indian Journal of Community Medicine 2004;29(1):41-3.

[17] Yunis K, Mumtaz G, Bitar F, et al. Consanguineous marriage and congenital heart defects- a case-control study in the neonatal period. American Journal of Medical Genetics A 2006;140(14):1524-30.

[18] Mosayebi Z, Movahedian AH. Pattern of congenital malformations in consanguineous versus nonconsanguineous marriages in Kashan, Islamic Republic of Iran. Eastern Mediterranean Health Journal 2007;13(4):869-75.

[19] Rajangam S, Devi R. Consanguinity and chromosomal abnormality in mental retardation and or multiple congenital anomaly. J Anat Soc India 2007;56(2):30-3.

[20] Yunis K, El-Rafei R, Mumtaz G. International Perspectives: consanguinity: perinatal outcomes and prevention - a view from the Middle East. Neo Reviews 2008;9(2):59-64.

[21] Tayebi N, Yazdani K, Naghshin N. The prevalence of congenital malformations and its correlation with consanguineous marriages. Oman Medical Journal 2010;25(1):37-40.

[22] Al-Kandari YY, Crews DE. The effect of consanguinity on congenital disabilities in the Kuwaiti population. Journal of Biosocial Science 2011;43(1):65-73.

[23] Stevenson AC, Johnston HA, Stewart MI, et al. Congenital malformations. A report of a study of series of consecutive births in 24 centres. Bull World Health Organ 1966;(34 Suppl 9):1-127.

[24] Magnus P, Berg K, Bjerkedal T. Association of parental consanguinity with decreased birth weight and increased rate of early death and congenital malformations. Clin Genet 1985;28(4)335-42.

[25] Orstavik KH, Lindemann R, Steen J. Infant death and con- sanguineous marriage. (Letter). BMJ 1994;308(6929):659.

[26] Sureender S, Prabakaran B, Khan AG. Mate selection and its impact on female marriage pregnancy wastages and first child survival in Tamil Nadu, India. Social Biology 1998;45(3-4):289-301.

[27] Reddy RV, Rao PA. Acta genetics medicine. Gemellol (ROMA) 1978;27:89-93. 
[28] Dronamraju KR, Khan PM. The frequency and effects of consanguineous marriages in Andhra Pradesh. J Genetics 1963;58(3):387-401.

[29] Bromiker R, Glam-Baruch M, Gofin R, et al. Association of parental consanguinity with congenital malformations among Arab newborns in Jerusalem. Clinical Genetics 2004;66(1):63-6.

[30] Anand JS, Javedekar BB, Belani M. Congenital Malformations in 2000 consecutive births. Indian Pediatrics 1988;25(9):845-51.

[31] Bittles A. Consanguinity and its relevance to clinical genetics. Clinical Genetics 2001;60(2):89-98.

[32] Bittles AH. The impact of consanguinity on the Indian population. Indian Journal of Human Genetics 2002;8(2):45-51.

[33] Becker SM, Al Halees Z, Molina C, et al. Consanguinity and congenital heart disease in Saudi Arabia. Am J Med Genet 2001;99(1):8-13.
[34] Bassili A, Mokhtar SA, Dabous NI, et al. Risk factors for congenital heart diseases in Alexandria, Egypt. Eur J Epidemiol 2000;16(9):805-14.

[35] Nabulsi MM, Tamim H, Sabbagh M, et al. Parenteral consanguinity and congenital heart malformations in a developing country. Am J Med Genet A 2003;116A(4):342-7.

[36] Ramegowda S, Ramachandra NB. Parental consanguinity increases congenital heart diseases in South India. Ann Hum Biol 2006;33(5-6):519-28.

[37] Oyen N, Poulsen G, Boyd HA, et al. Recurrence of congenital heart defects in families. Circulation 2009;120(4):295-301.

[38] Bennett RL, Hudgins L, Smith CO, et al. Inconsistencies in genetic counseling and screening for consanguineous couples and their offspring: the need for practice guidelines. Genet Med 1999;1(6):286-92. 